\title{
Quantitative Measurement of Mucolytic Enzymes in Fecal Samples
}

Shahanshah Khan and Hasan Zaki*

Department of Pathology, UT Southwestern Medical Center, Dallas, TX, USA

*For correspondence: Hasan.Zaki@utsouthwestern.edu

\begin{abstract}
[Abstract] The mucus layer in the gastrointestinal tract covers the apical surface of intestinal epithelial cells, protecting the mucosal tissue from enteric pathogen and commensal microorganisms. The mucus is primarily composed of glycosylated protein called mucins, which are produced by goblet cells, a type of columnar epithelial cells in the intestinal tract. Defective mucin barrier facilitates infection caused by enteric pathogen and triggers inflammation due to invasion of commensal or opportunistic pathogens into the intestinal epithelial mucosa. Several bacterial species in the gut produce enzymes that are capable of degradation of the mucus. Defective mucin production or increased abundance of mucolytic bacteria are clinically linked to inflammatory bowel disease. Measurement of mucolytic enzymes in the feces, therefore, can be implicated in clinical and experimental research on intestinal disorders. Here, we describe a step-by-step procedure for the measurement of the mucolytic enzyme activity in fecal samples.
\end{abstract}

Keywords: Mucus, Mucin, Mucolytic enzymes, Mucus degrading bacteria

[Background] The gastrointestinal tract $(\mathrm{Gl})$ is home for trillions of microorganisms which play diverse functions in the physiological processes (Sommer and Backhed, 2011). Commensal gut microbiota process undigested food, provide energy, nutrients and vitamins, activate the immune system, and prevent pathogens from infecting the intestinal mucosal tissue (Round and Mazmanian, 2009; Pickard et al., 2017). Despite these beneficial roles, gut commensal microorganisms may act as opportunistic pathogens when they get the opportunity to colonize intestinal epithelial barrier and invade into the mucosal tissue. However, a gel like mucus layer above the apical surface of the epithelial cells throughout the intestinal tract ensures physical separation of commensal microbes from the intestinal mucosal tissue and helps maintain intestinal homeostasis (Pullan et al., 1994; Linden et al., 2008; Atuma et al., 2011; Johansson et al., 2011; Juge, 2012). In the large intestine, mucus barrier is very thick, about $700 \mathrm{~nm}$, and can be divided into two distinct layers - a thick outer layer and a thin inner layer (Johansson et al., 2008 and 2011). While the outer layer is nutrient rich, easy to be dislodged, and often colonized with anaerobic bacteria, the inner layer is firmly attached to the epithelial layer and is mostly sterile (Johansson et al., 2008 and 2011).

The mucus is primarily composed of glycoprotein called mucin, produced by goblet cells which are a type of columnar epithelial cells in the intestinal tract. Upon synthesis, mucin proteins are O-glycosylated or N-glycosylated with oligosaccharides and transported to the cell surface or secreted outside (McGuckin et al., 2011). Secretory mucins are heavily O-glycosylated and are homo-oligomerized via inter-molecular disulphide bond formed between the cysteine-rich $\mathrm{D}$ domain at the $\mathrm{C}$ and $\mathrm{N}$ terminus 
(Thornton et al., 2008). The major mucins in the outer layer that oligomerize to form the matrix are MUC2, MUC5AC, MUC5B, MUC6, and MUC19 (Thornton et al., 2008; McGuckin et al., 2011). The mucus is embedded with many antimicrobial peptides and immunoglobulins, which also keep the inner mucus layer sterile (McGuckin et al., 2011). On the other hand, oligosaccharides of the mucin serve as ligands and a source of nutrients for many anaerobic bacteria. Thus, several intestinal commensals as well as pathogens produce mucolytic enzymes, such as sulphatase, proteases, neuraminidases, $\alpha$-glycosidase, $\beta$-glycosidase, $\beta$-galactosidase, fucosidase, $\beta$ - $\mathrm{N}$-acetylglucosaminidase, $\alpha-\mathrm{N}$-acetylgalactosaminidase, etc., to degrade mucins (Corfield et al., 1992; Linden et al., 2008; Johansson et al., 2011; Desai et al., 2013). Based on the diversity and complexity of mucin oligomers, cooperative actions are required from a number of enzymes as mentioned above for the degradation of mucins (Lombard et al., 2014). The major mucosa-associated bacteria belong to the phyla Proteobacteria, Actinobacteria, Firmicutes, Bacteroidetes, and Verrucomicrobia (Derrien et al., 2010; Tailford et al., 2015).

Enzymatic degradation of the mucus layer allows gut commensal bacteria or pathogen to breach the mucus barrier (Khan et al., 2020). Therefore, increased abundance of mucolytic bacteria facilitates enteric infection and is associated with inflammatory bowel diseases (IBD) such as Crohn's disease and ulcerative colitis (Prizont, 1982; Carroll et al., 2010; Png et al., 2010; Hansson, 2012; Sheng et al., 2012). Thus, the level of mucus degrading enzymes in the colon could be a predictive marker for IBD. Measurement of mucolytic enzymes is also very useful in studies aimed at dissecting the mechanism of IBD pathogenesis in experimental or clinical settings.

\section{Materials and Reagents}

1. $1.7 \mathrm{ml}^{\text {Posi-Click }}{ }^{\mathrm{TM}}$ Tubes (Denvelle, catalog number: $\mathrm{C} 2170$ )

2. 96-well flat bottom plate (Thermo Scientific, catalog number: 12565136)

3. Aluminium foil (Fisher Brand, catalog number: 01-213-100)

4. Micropipette barrier tips (from $10 \mu \mathrm{l}$ to $1,000 \mu \mathrm{l}$ ) (Genesee Scientific)

5. 8-10 weeks-old C57BI6/j mice

6. 4-nitrophenol (Sigma-Aldrich, catalog number: 241326-50G)

7. 4-nitrophenyl $\mathrm{N}$-acetyl- $\beta$-D-glucosaminide (Sigma-Aldrich, catalog number: N9376)

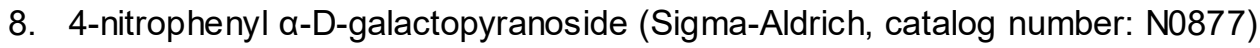

9. 4-nitrophenyl $\beta$-D-glucopyranoside (Sigma-Aldrich, catalog number: N7006)

10. Fresh or $-80^{\circ} \mathrm{C}$ stored feces pellets

11. Acetone (EM Science, catalog number: AX0120-8)

12. DNases (Sigma-Aldrich, catalog number: 11284932001)

13. Lysozyme (Fisher BioReagents ${ }^{\mathrm{TM}}$, catalog number: BP535-1)

14. Magnesium chloride $\left(\mathrm{MgCl}_{2}\right)$ (Sigma-Aldrich, catalog number: $\left.\mathrm{M}-0250\right)$

15. Methanol (Fisher Chemical, catalog number: A433P-4)

16. p-nitrophenyl $\alpha$-L-fucopyranoside (Sigma-Aldrich, catalog number: N3628)

17. $p$-nitrophenyl $\beta$-D-xylopyranoside (Sigma-Aldrich, catalog number: N2132) 
18. Pierce ${ }^{\mathrm{TM}}$ BCA protein assay kit (Thermo Scientific, catalog number: 23227 )

19. Potassium chloride (KCl) (Sigma-Aldrich, catalog number: P9541-500G)

20. Protease inhibitor cocktail tablet (Roche, catalog number: 26733200)

21. Triton X-100 (Sigma-Aldrich, catalog number: T-9284)

22. Trizma ${ }^{\circledR}$ hydrochloride (Sigma-Aldrich, catalog number: S8045-1KG)

23. 4-Nitrophenyl (4NP) standard curve (see Recipes)

24. Mucolytic enzyme buffer (see Recipes)

25. Nitrophenyl-linked substrates and their corresponding mucolytic enzymes (see Recipes)

\section{Equipment}

1. A pair of sterile forceps

2. $-80{ }^{\circ} \mathrm{C}$ freezer (Thermo Scientific)

3. Centrifuge (Thermo Scientific, Legend Micro 21R)

4. Ice making machine (Hoshizaki American Inc.)

5. Micropipette (from $10 \mu \mathrm{l}$ to $1,000 \mu \mathrm{l}$ ) (Labnette)

6. Multi-channel pipette $(300 \mu \mathrm{l})$ (Fisher Brand)

7. Sonicator with $3 \mathrm{~mm}$ tapered microtip (Branson Digital Sonifier, Model: 102C)

8. Spectrophotometer (TECAN, SPARK 10M)

9. Vortex Genie 2 (VWR Scientific Products)

10. Weighing balance (ADAM Equipment, PW124)

\section{Procedure}

1. Collect 2-3 fecal pellets (approximately $50 \mathrm{mg}$ ) from each mouse into a tube.

Note: Feces can be stored at $-80^{\circ} \mathrm{C}$ until measurement.

2. Add $0.5 \mathrm{ml}$ of ice-cold mucolytic enzyme buffer (Recipe 1) into the tube containing fecal pellets and gently vortex.

Note: Vertexing is not necessary if feces are not solid.

3. Sonicate samples using ultrasonic processor for $5 \mathrm{~s}$ with $35 \%$ amplitude and $3 \mathrm{~mm}$ tapered microtip on ice. Repeat ultrasonication following a $10 \mathrm{~s}$ interval for a total of 9 cycles or $45 \mathrm{~s}$.

4. Centrifuge sonicated samples at $10,000 \times g$ for $10 \mathrm{~min}$ at $4{ }^{\circ} \mathrm{C}$.

5. Transfer $\sim 400 \mu \mathrm{l}$ supernatant into fresh $1.5 \mathrm{ml}$ tubes and measure protein concentration. Note: Supernatant can be stored at $-80^{\circ} \mathrm{C}$, until measurement.

6. Adjust the protein concentration to $1 \mathrm{mg} / \mathrm{ml}$ by adding ice-cold mucolytic enzyme buffer.

7. Transfer $5 \mu \mathrm{l}$ ( $5 \mu \mathrm{g}$ protein) supernatant of a particular fecal sample into three wells ( $5 \mu \mathrm{l}$ each) of a 96-well flat-bottom plate. Add $150 \mu \mathrm{l}$ of a specific $10 \mathrm{mM}$ nitrophenyl-based substrate (Recipe 2) prepared in ice-cold mucolytic enzyme buffer. For each enzyme tested, 
corresponding substrate is added into triplicate wells containing the same sample. These procedures are repeated when multiple samples are used.

8. Measure the absorbance at $405 \mathrm{~nm}$ in a plate reader at $37^{\circ} \mathrm{C}$ at every $30 \mathrm{~min}$ interval.

9. Using a known concentration of 4-nitrophenol standard curve (Recipe 3), determine the individual mucolytic enzyme activity (Figure 1).
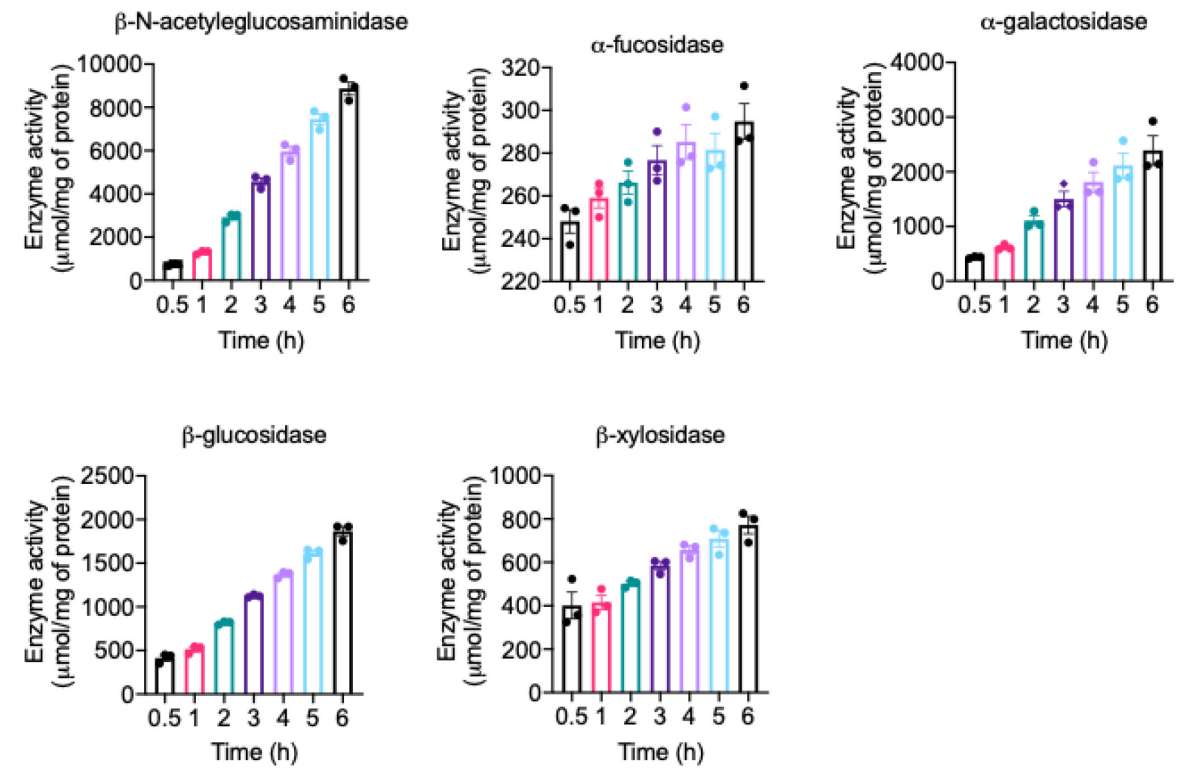

Figure 1. Time-dependent mucolytic enzymatic activity in mouse fecal samples. Fecal samples collected from healthy mouse were homogenized and processed as described in the protocol. The activity of indicated enzymes was measured in the fecal lysate following the procedure described in the protocol.

\section{$\underline{\text { Recipes }}$}

1. Mucolytic enzyme buffer ( $\mathrm{pH} 7.25)$

Stock solution

Working solution

For $100 \mathrm{ml}$

$1 \mathrm{M}$ Tris

$50 \mathrm{mM}$

$1 \mathrm{M} \mathrm{KCl}$

$100 \mathrm{mM}$

$1 \mathrm{M} \mathrm{MgCl}_{2}$

$10 \mathrm{mM}$

Lysozyme

5-10 mg

12\% Triton X-100

$100 \mu \mathrm{l}$

DNases

5-10 mg

Protease inhibitor

One tablet

2. Nitrophenyl-linked substrates and their corresponding mucolytic enzymes

Nitrophenyl-linked substrates

Mucolytic enzymes

4-nitrophenyl a-D-galactopyranoside

a-galactosidase

Plant glycans 
4-nitrophenyl N-acetyl- $\beta$-D-glucosaminide

4-nitrophenyl $\beta$-D-glucopyranoside

p-nitrophenyl $\alpha$-L-fucopyranoside

p-nitrophenyl $\beta$-D-xylopyranoside
$\beta$-N-acetylglucosaminidas

$\beta$-glucosidase

$\alpha$-fucosidase

$\beta$-xylosidase
Mucin

Plant glycans

Mucin

Plant glycans

Note: We mentioned above nitrophenyl-linked substrates, which we use in the Figure 1.

3. 4-Nitrophenol (4NP) standard curve

4-Nitrophenol (4NP) is an enzymatic product of p-nitrophenyl-linked substrates. The amount of 4NP produced during reaction of mucolytic enzymes with its substrate corresponds to the mucolytic enzyme activity (Recipe 2). 4NP provides yellow color and can be measured spectrophotometrically at $405 \mathrm{~nm}$. Thus, a standard curve of 4NP can be used to measure mucolytic enzyme activity in a reaction mixture of mucolytic enzymes and its p-nitrophenyllinked substrates.

a. Prepare a $100 \mathrm{mM} 4 \mathrm{NP}(\mathrm{MW}=139.11)$ stock solution by dissolving $0.0139 \mathrm{~g}(13.9 \mathrm{mg})$ of $4 \mathrm{NP}$ in $1 \mathrm{ml}$ of methanol.

b. Prepare a working stock solution of $1 \mathrm{mM} 4 \mathrm{NP}$ (from $100 \mathrm{mM} \mathrm{4NP)}$ for standard curve with mucin enzyme assay buffer.

c. Prepare a series of $4 \mathrm{NP}$ concentration ranging from 0 to $1,000 \mu \mathrm{M}$ (or 0 to $1 \mathrm{mM}$ ) from the working stock (1 $\mathrm{mM}$ ) prepared in mucin enzyme assay buffer.

d. Add $150 \mu \mathrm{l}$ of each standard solution into a 96-well plate including blank and read the absorbance with a spectrophotometer at $405 \mathrm{~nm}$ at $37^{\circ} \mathrm{C}$.

e. Plot the standard curve with known standard concentration on the X-axis and absorbance on the Y-axis.

\section{Acknowledgement}

This protocol was adapted with minor modification from previous study published by Desai et al. (2016) and Khan et al. (2020). We would like to thank the UT Southwestern Animal Resource Center (ARC) for maintenance and care of our mouse colony. This work was supported by The National Institute of Diabetes and Digestive and Kidney Diseases (NIDDK) of the National Institute of Health (NIH) under Award Number R01DK125352, and Cancer Prevention and Research Institute of Texas (CPRIT) Individual Investigator Awards (RP200184), and UT Southwestern funding given to H.Z.

\section{Competing interests}

The authors declare no competing interests.

\section{Ethics}

This study was approved by the Institutional Animal Care and Use Committee (IACUC; approval No. 
Please cite this article as: Khan and Zaki, (2021). Quantitative Measurement of Mucolytic Enzymes in Fecal Samples,Bio-protocol 11 (6): e3956. DOI:

2016-101683), and was conducted in accordance with the IACUC guidelines.

\section{$\underline{\text { References }}$}

1. Atuma, C., Strugala, V., Allen, A. and Holm, L. (2001). The adherent gastrointestinal mucus gel layer: thickness and physical state in vivo. Am J Physiol Gastrointest Liver Physiol 280(5): G922929.

2. Carroll, I. M., Chang, Y. H., Park, J., Sartor, R. B. and Ringel, Y. (2010). Luminal and mucosalassociated intestinal microbiota in patients with diarrhea-predominant irritable bowel syndrome. Gut Pathog 2(1): 19.

3. Corfield, A. P., Wagner, S. A., Clamp, J. R., Kriaris, M. S. andHoskins, L. C. (1992). Mucin degradation in the human colon: production of sialidase, sialate O-acetylesterase, $\mathrm{N}$ acetylneuraminate lyase, arylesterase, and glycosulfatase activities by strains of fecal bacteria. Infect Immun 60(10): 3971-3978.

4. Desai, M. S., Seekatz, A. M., Koropatkin, N. M., Kamada, N., Hickey, C. A., Wolter, M., Pudlo, N. A., Kitamoto, S., Terrapon, N., Muller, A., Young, V. B., Henrissat, B., Wilmes, P., Stappenbeck, T. S., Nunez, G. and Martens, E. C. (2016). A dietary fiber-deprived gut microbiota degrades the colonic mucus barrier and enhances pathogen susceptibility. Cell 167(5): 1339-1353 e1321.

5. Derrien, M., van Passel, M. W., van de Bovenkamp, J. H., Schipper, R. G., de Vos, W. M. and Dekker, J. (2010). Mucin-bacterial interactions in the human oral cavity and digestive tract. Gut Microbes 1(4): 254-268.

6. Hansson, G. C. (2012). Role of mucus layers in gut infection and inflammation. Curr Opin Microbiol 15(1): 57-62.

7. Johansson, M. E., Larsson, J. M. and Hansson, G. C. (2011). The two mucus layers of colon are organized by the MUC2 mucin, whereas the outer layer is a legislator of host-microbial interactions. Proc Natl Acad Sci U S A 108 Suppl 1: 4659-4665.

8. Johansson, M. E., Phillipson, J. M., Petersson, J., Velcich, A., Holm, L. and Hansson, G. C. (2008). The inner of the two Muc2 mucin-dependent mucus layers in colon is devoid of bacteria. Proc Natl Acad Sci U S A 105(39): 15064-15069.

9. Juge, N. (2012). Microbial adhesins to gastrointestinal mucus. Trends Microbiol 20(1): 30-39.

10. Khan, S., Waliullah, S., Godfrey, V., Khan, M. A. W., Ramachandran, R. A., Cantarel, B. L., Behrendt, C., Peng, L., Hooper, L. V., Zaki, H. (2020). Dietary simple sugars alter microbial ecology in the gut and promote colitis in mice. Sci Transl Med 12: eaay6218.

11. Linden, S. K., Sutton, P., Karlsson, N. G., Korolik, V. and McGuckin, M. A. (2008). Mucins in the mucosal barrier to infection. Mucosal Immunol 1(3): 183-197.

12. Lombard, V., Golaconda Ramulu, H., Drula, E., Coutinho, P. M. and Henrissat, B. (2014). The carbohydrate-active enzymes database (CAZy) in 2013. Nucleic Acids Res 42: D490-495.

13. McGuckin, M. A., Linden, S. K., Sutton, P. and Florin, T. H. (2011). Mucin dynamics and enteric 
pathogens. Nat Rev Microbiol 9(4): 265-278.

14. Pickard, J. M., Zeng, M. Y., Caruso, R. and Nunez, G. (2017). Gut microbiota: Role in pathogen colonization, immune responses, and inflammatory disease. Immunol Rev 279(1): 70-89.

15. Png, C. W., Linden, S. K., Gilshenan, K. S., Zoetendal, E. G., McSweeney, C. S., Sly, L. I., McGuckin, M. A. and Florin, T. H. (2010). Mucolytic bacteria with increased prevalence in IBD mucosa augment in vitro utilization of mucin by other bacteria. Am J Gastroenterol 105(11): 2420-2428.

16. Prizont, R. (1982). Degradation of intestinal glycoproteins by pathogenic Shigella flexneri. Infect Immun 36(2): 615-620.

17. Pullan, R. D., Thomas, G. A., Rhodes, M., Newcombe, R. G., Williams, G. T., Allen, A. and Rhodes, J. (1994). Thickness of adherent mucus gel on colonic mucosa in humans and its relevance to colitis. Gut 35(3): 353-359.

18. Round, J. L. and Mazmanian, S. K. (2009). The gut microbiota shapes intestinal immune responses during health and disease. Nat Rev Immunol 9(5): 313-323.

19. Sheng, Y. H., Hasnain, S. Z., Florin, T. H. and McGuckin, M. A. (2012). Mucins in inflammatory bowel diseases and colorectal cancer. J Gastroenterol Hepatol 27(1): 28-38.

20. Sommer, F. and Backhed, F. (2013). The gut microbiota--masters of host development and physiology. Nat Rev Microbiol 11(4): 227-238.

21. Tailford, L. E., Crost, E. H., Kavanaugh, D., Juge, N. (2015). Mucin glycan foraging in the human gut microbiome. Front Genet 6: 81.

22. Thornton, D. J., Rousseau, K. and McGuckin, M. A. (2008). Structure and function of the polymeric mucins in airways mucus. Annu Rev Physiol 70: 459-486. 